Plant Tissue Cult. \& Biotech. 24(1): 101-109, 2014 (June)

$\overline{\text { PTC\&B }}$

\title{
Micropropagation of Environmental Stress Tolerant Local Potato (Solanum tuberosum L.) Varieties of Bangladesh
}

\section{Fazlima Parveen, Mahmuda Khatun ${ }^{1}$ and Aparna Islam*}

Biotechnology Programme, Department of Mathematics and Natural Sciences, BRAC University, Dhaka, Bangladesh

Key words: Potato, Indigenous varieties, In vitro regeneration, Abiotic stress, Nodal explant, Shoot apex

\begin{abstract}
In vitro response of four explants namely, leaf, shoot apex, nodal and internodal, in three stress tolerant Bangladeshi potato varieties, viz. Zaubilati, Shadaguti and Challisha were tested. Of all the varieties, Shadaguti responded best for all the explants. Among the explants nodal segment responded best, followed by shoot apex. For all these explants and varieties, shoot regeneration response was tested in response to two cytokines, BAP and $\mathrm{Kn}$. When compared between BAP and Kn supplementation, Kn treatment performed better than that of BAP for nodal and shoot apex, while opposite was observed for remaining explants. Interestingly, hormone free basal PROP medium was found to be best for nodal explants of both Zaubilati and Challisha varieties. While nodal explants of Shadaguti showed the best result in $0.5 \mathrm{mg} / \mathrm{Kn}$. Shoot apex performed best in $0.5 \mathrm{mg} / \mathrm{l} \mathrm{Kn}$ for all the varieties. As an explant both internode and leaf did not perform well. Direct regeneration from these explants was found best in PROP + $0.2 \mathrm{mg} / \mathrm{l} \mathrm{GA} 3+0.5 \mathrm{mg} / \mathrm{l} \mathrm{IAA} ; 1.0 \mathrm{mg} / \mathrm{l} \mathrm{BAP}, 1.5 \mathrm{mg} / \mathrm{l} \mathrm{BAP}$ and $2.0 \mathrm{mg} / \mathrm{l} \mathrm{BAP}$ for Zaubilai, Challisha and Shadaguti, respectively. For rooting, of the in vitro grown shoots half strength of PROP medium supplemented with $0.5 \mathrm{mg} / \mathrm{l}$ IBA was found to be best. Cent percent survival of transplanted plantlets was recorded. The successful protocol for in vitro regeneration was developed which can be used for large scale production of these abiotic stress tolerant potato varieties.
\end{abstract}

\section{Introduction}

Bangladesh is an agriculture-based country having 30 per cent of her cultivated land located in the coastal areas. Due to climate change 53 per cent of this coastal area is affected by various degree of salinity (Uddin et al. 2011). This imposes not

*Author for correspondence: aparna@bracu.ac.bd, aparnai20@yahoo.com ${ }^{1}$ Biotechnology Division, Bangladesh Agricultural Research Institute (BARI), Gazipur, Dhaka, Bangladesh. 
only salinity but also drought stress and affects almost all biochemical functions (Das et al. 2013). As a result food security is becoming a big challenge for Bangladesh.

Potato, the edible tuber of the cultivated plant Solanum tuberosum L. belongs to the economically important family, Solanaceae. It is one of the most important vegetable crops in Bangladesh securing second position as a staple crop following rice (BBS 2012). Nutritionally, the tuber is rich in carbohydrates and is a good source of protein, vitamin $\mathrm{C}$ and $\mathrm{B}$, potassium, phosphorus, and iron; while its skin is a source of food fiber (Sharfuddin et al. 1985). Potato is in great demand throughout the year. Potato varieties cultivated in Bangladesh are broadly categorized into two groups, local or indigenous and high yielding varieties (HYVs). The HYVs are under cultivation to meet the food demand. But recently, susceptibility of these HYVs toward salinity stress has resulted in tuber yield loss, thus, making them unsuitable for cultivation (Rahman et al 2013, Uddin et al. 2010). To overcome these problems we need to cultivate stress tolerant varieties to ensure higher production. Indigenous varieties, namely, Shadaguti and Zaubilati have been reported to be salt tolerant, while Challisha highly nutritious (Khatun et al. 2010 and 2011). Since the 1990s, plant tissue culture of potato is playing an important role in generating potato seeds (Hoque et al. 1996). Mass propagation of these local varieties through tissue culture for commercial cultivation may ensure better yields under stress conditions such as salinity. Unfortunately, there are very few reports on the seed producing capacities of Bangladeshi varieties and none on the stress tolerant varieties.

In potato, cytokinin has been reported essential for morphogenesis. But the genotype and the explant interaction influence this requirement (Ritchie and Hodges 1993). Several explants ranging from leaflets, tuber discs, nodes and internodes, shoot apex have been exploited to establish a regeneration system (Shirley et al. 2001, Trujillo et al. 2001, Sarker and Mustafa 2002, Hussain et al. 2005). In the present study, the morphogenic potential of four kinds of explants of three indigenous potato varieties have been evaluated to establish their in vitro regeneration protocol and determine their suitability for micropropagation.

\section{Materials and Methods}

Salt stress tolerant local potato varieties, viz. Zaubilati, Shadaguti and nutritious variety Challisha were collected from Tuber Crops Research Centre (TCRC), Bangladesh Agricultural Research Institute (BARI), Gazipur, Bangladesh.

Potato tubers were kept in the dark at $12^{\circ} \mathrm{C}$. The potato sprouts were thoroughly washed under running tap water for 30 min with detergent to

remove surface contamination. Finally, sprouts were sterilized by dipping 
sequentially in ethanol for $20 \mathrm{sec}$ and then in $0.1 \%(\mathrm{w} / \mathrm{v}) \mathrm{HgCl}_{2}$ for $1 \mathrm{~min}$. Thereafter, sprouts were washed three to fourtimes with autoclaved distilled water to remove the traces of sterilants. The sterilized sprouts were excised into $0.2-0.4 \mathrm{~cm}$ pieces and were transferred to culture media for sprout regeneration. Explants, such as shoot apex, node, internode and leaf were collected from these in vitro grown shoots. Explants were cultured on PROP (Haberlacha et al. 1985) medium supplemented with either BAP or $\mathrm{Kn}(0.5-2.5 \mathrm{mg} / \mathrm{l})$. The $\mathrm{pH}$ was adjusted to 5.8 before autoclaving. Cultures were maintained at $16 \mathrm{hrs}$ photoperiod at $25 \pm 2{ }^{\circ} \mathrm{C}$. In some cases, several roots developed spontaneously from in vitro grown shoots. But they were found to be inadequate for transplantation. Hence, shoots of $3-4 \mathrm{~cm}$ in length were excised, and cultured on different rooting media, such as PROP, 1/2 PROP, 1/2 PROP + $0.1 \mathrm{mg} / 1 \mathrm{IBA}, 1 / 2$ PROP + $0.5 \mathrm{mg} / \mathrm{l} \mathrm{IBA}$.

Regenerated plantlets with sufficient roots $(3-5 \mathrm{~cm}$ in length) were transferred in soil. Before transfer to soil, rooted plantlets were kept for 5 - 7 days at room temperature $\left(30 \pm 2^{\circ} \mathrm{C}\right)$ for acclimation. After that, plantlets were taken out from the test tubes, washed carefully under running tap water to remove any traces of agar. Then each plantlet was transferred into a small plastic pot containing garden soil, sand and decomposed cow dung at the ratio of $1: 1: 1$ and kept in shade house for proper hardening. All the experiments were repeated three times with 20 samples in each treatment.

\section{Results and Discussions}

Both shoot apex and nodal explants showed direct regeneration in media fortified with either of BAP or $\mathrm{Kn}$ in all three varieties. Among the two explants, nodal explants showed slightly better result than shoot apex. The best concentration of BAP for shoot regeneration was found to be $1.5 \mathrm{mg} / \mathrm{l}$ for shoot apex explants in all varieties (Fig. 1). In case of nodal explants Shadaguti was found to be best in presence of $1.5 \mathrm{mg} / \mathrm{l} \mathrm{BAP}$, while nodal segments of the other two varieties responded better in PROP medium without any cytokinins (Table 1). In case of $\mathrm{Kn}$ supplementation, $0.5 \mathrm{mg} / \mathrm{l}$ was found to be the best for shoot apex explants in all the three varieties (Fig. 2). Nodal explants of Shadaguti variety also responded best in the presence of $0.5 \mathrm{mg} / \mathrm{l} \mathrm{Kn}$, while the other two varieties showed best response in cytokinin free PROP (Fig. 3). Comparison between BAP and Kn supplements, found that $\mathrm{Kn}$ gave better results than BAP in all parameters of shoot regeneration in these explants.

In contrast to the above two explants, both internode and leaf explants failed to respond to either of the cytokinins alone. So, constant concentration of $\mathrm{GA}_{3}$ $(0.2 \mathrm{mg} / \mathrm{l})$ and IAA $(0.5 \mathrm{mg} / \mathrm{l})$ were applied along with various concentrations $(0.5$ 
- $2.5 \mathrm{mg} / \mathrm{l}$ ) of BAP or Kn. For direct shoot regeneration, 1.5 and $2.0 \mathrm{mg} / \mathrm{l} \mathrm{BAP}$ with $\mathrm{GA}_{3}(0.2 \mathrm{mg} / \mathrm{l})$ and IAA $(0.5 \mathrm{mg} / \mathrm{l})$ were found best for internode and leaf explant of Shadaguti and Challisha, respectively. Internode and leaf explants of Zaubilai responded best in 1.0 and $1.5 \mathrm{mg} / \mathrm{l} \mathrm{BAP}$, respectively (Table 2). Supplementation of $\mathrm{Kn}$ along with $\mathrm{GA}_{3}$ and IAA either failed to generate any response or gave response less than 20\%. Results revealed that Shadaguti remained the best responding variety for in vitro direct regeneration and internode explant showed slightly better shoot regeneration capacity than leaf explants. However, here BAP performed better than $\mathrm{Kn}$ treatments for direct shoot regeneration. Nonetheless, these two explants showed poor result compared to nodal and shoot apex explants.

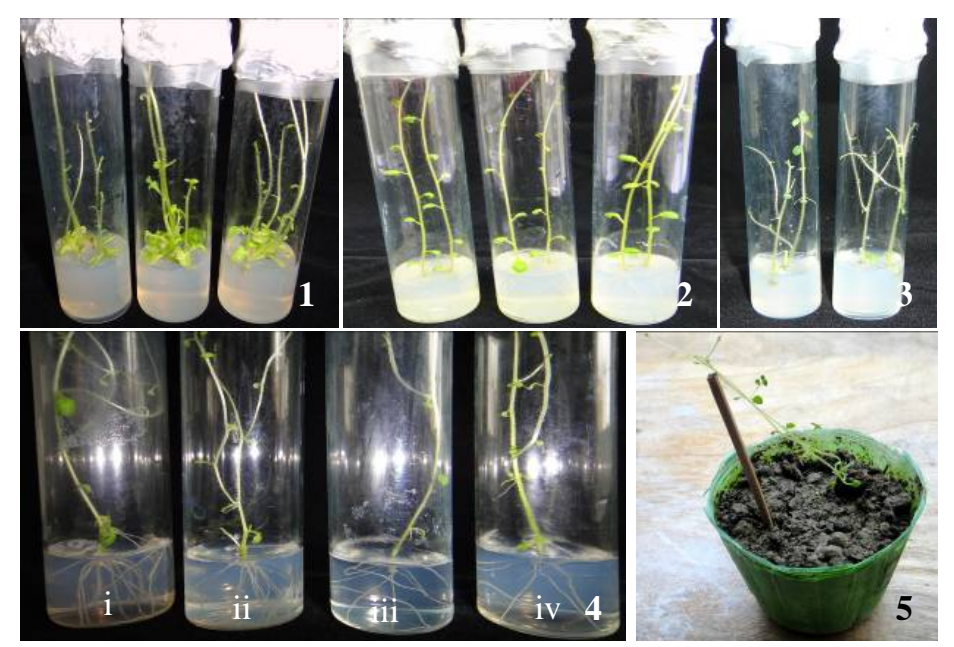

Figs 1 - 3. Fully developed multiple shoots from shoot apex of Shadaguti in PROP with $1.5 \mathrm{mg} / \mathrm{l} \mathrm{BAP}$ (Fig. 1); from the shoot apex of Shadaguti in PROP with $0.5 \mathrm{mg} / \mathrm{l} \mathrm{Kn}$ (Fig. 2); from nodal segments of Challisha in RMOP only (Fig. 3). Fig. 4. Root formation in the Shadaguti variety in four different media $(\mathrm{i}=1 / 2$ PROP $+0.5 \mathrm{mg} / \mathrm{lBA}, \mathrm{ii}=1 / 2 \mathrm{PROP}+0.1 \mathrm{mg} / \mathrm{lBA}$, iii $=1 / 2$ PROP, $\mathrm{iv}=$ Full PROP). Fig 5. Ex vitro established potato plantlets of the Shadaguti variety. Photographs were taken four weeks after inoculation.

Till to date only HYVs have been used for generating potato plantlets in vitro. These HYVs have, however, shown to be salinity susceptible (Rahman et al. 2013). But under present scenario of climate change, it is important to develop regeneration protocol for salt tolerant potato varieties. Fortunately, a few local varieties are tolerant to salinity stress (Khatun et al. 2010). Therefore, in the present study explants that were reported to be good for HYVs were explored to establish regeneration protocol in local salt tolerant varieties. In commercial varieties like, Diamant, Cardinal and Heera, both BAP and IAA requirement was 


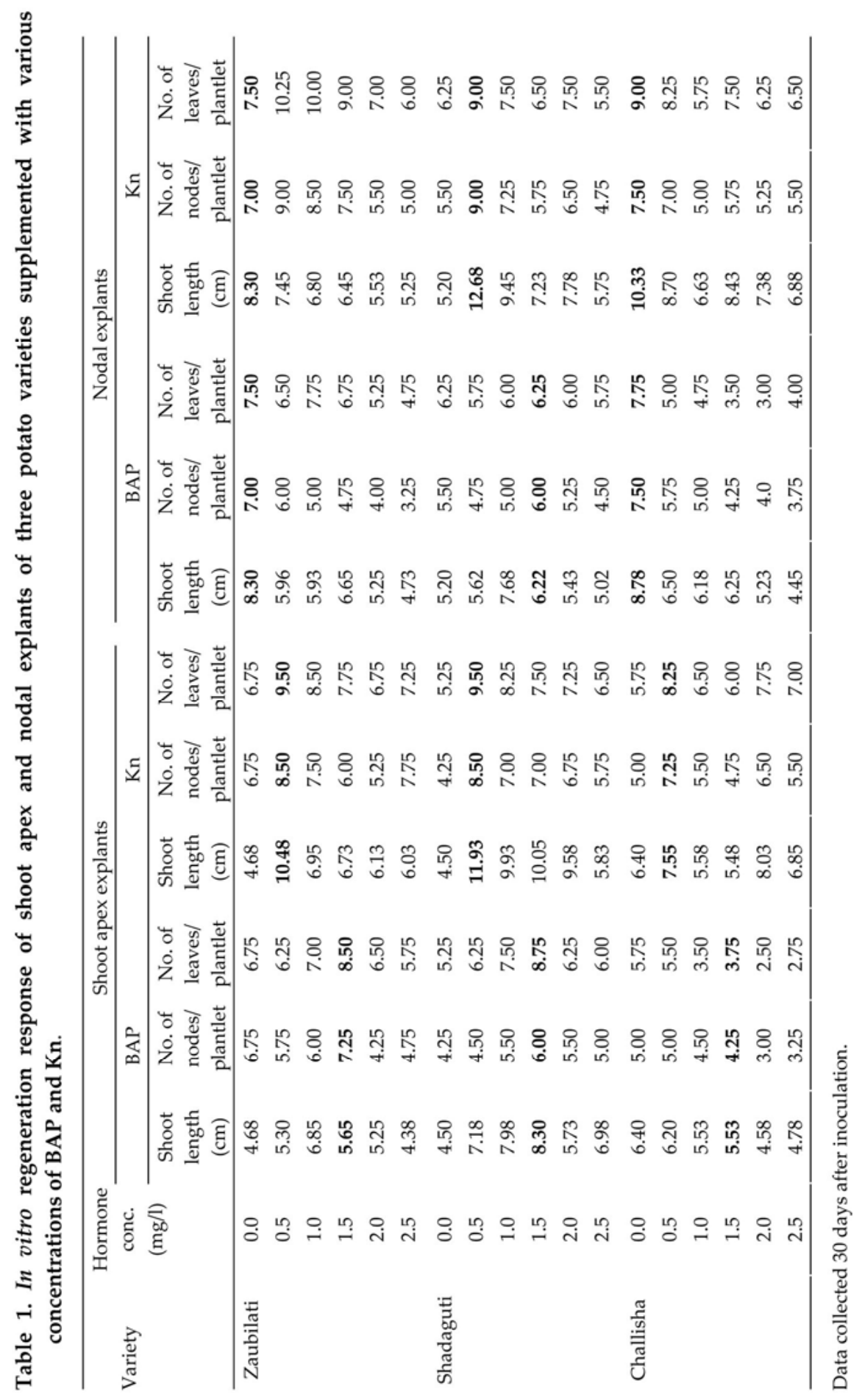




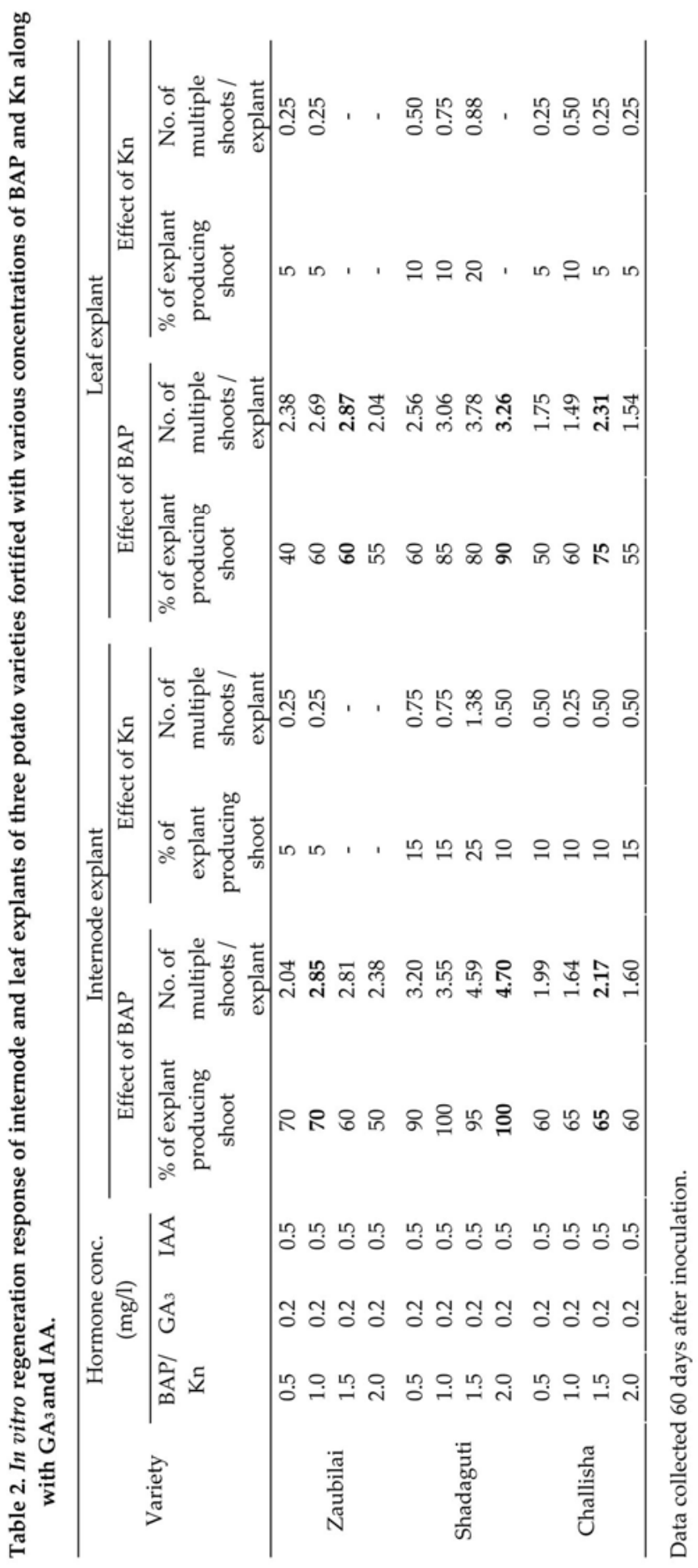


reported for nodal and internal explants (Borna et al. 2010, Hussain et al. 2005, Sarker and Mustafa 2002, Philip and Hampson 1995), while for leaf and internodes, NAA and BAP were reported to be the best (Khatun et al. 2012). Both studies are different from our observation. This variation may be due to the different genotypes. Borna et al. (2010) reported direct regeneration from node and internode explants. Hussain et al. (2005) reported direct regeneration from node and shoot apex, while indirect regeneration occurred from leaf and internode. In here, direct morphogenesis was observed from all the explants. Among the explants, node responded the best in the present study. This is in agreement with Hussain et al. (2005).

Table 3. Effect of basal media and different concentrations of IBA on rooting of in vitro regenerated shoots of Shadaguti variety.

\begin{tabular}{lccccc}
\hline \multicolumn{1}{c}{ Medium } & $\begin{array}{c}\text { Days to } \\
\text { root } \\
\text { initiation }\end{array}$ & $\begin{array}{c}\text { No. of } \\
\text { roots } / \\
\text { plantlet }\end{array}$ & $\begin{array}{c}\text { Root length } \\
(\mathrm{cm}) / \\
\text { plantlet }\end{array}$ & $\begin{array}{c}\text { Visual } \\
\text { growth of } \\
\text { root }\end{array}$ & $\begin{array}{c}\text { Days required } \\
\text { for well } \\
\text { developed roots }\end{array}$ \\
\hline Full PROP & 9.0 & 5.50 & 5.90 & + & $18-21$ \\
12 PROP & 7.5 & 3.67 & 6.33 & + & $18-21$ \\
1/2 PROP + 0.1 & 6.33 & 8.83 & 5.95 & ++ & $16-18$ \\
mg/1 IBA & & & & & $12-14$ \\
12 PROP + 0.5 & 5.50 & 11.83 & 4.53 & +++ & - \\
mg/l IBA & & & & & - \\
LSD (0.01) & 0.695 & 1.23 & 0.54 & - & - \\
CV (\%) & 11.95 & 20.09 & 11.56 & - & - \\
\hline
\end{tabular}

Significant at $1 \%$ level of probability. Data collected 30 days after inoculation. $+=$ Poor, ++ $=$ Good, $+++=$ Very good, $-=$ Absent.

As Shadaguti variety was found to be consistent giving best response, shoots of this variety was taken for in vitro root formation. Rooting was observed in all four different media, viz. full strength PROP; half strength PROP with or without $0.1 \mathrm{mg} / \mathrm{l}$ or $0.5 \mathrm{mg} / \mathrm{lBA}$ (Fig 4). Half strength PROP with $0.5 \mathrm{mg} / \mathrm{l} \mathrm{IBA}$ was found to be best for all rooting (Table 3). However, Sarker and Mustafa (2002) reported $0.1 \mathrm{mg} / \mathrm{l}$ IAA best for rooting. All shoots with roots were transferred to soil where they successfully survived in the natural environment (Fig. 5).

All the stress tolerant potato varieties and all the four explants responded well. Considering the responses, Shadaguti was found to be the best responsive genotype for in vitro regeneration. Moreover, among the four explants nodal segments showed the best regeneration. Similar responses were recorded in case of shoot apex. Nodal segments of Zaubilati and Challisha responded best in PROP without any hormone. Nodal explants of Shadaguti along with shoot apex in all the varieties showed best response in RPOP with $1.5 \mathrm{mg} / \mathrm{l} \mathrm{BAP}$. For rooting, 
half strength PROP supplemented with $0.5 \mathrm{mg} / \mathrm{l} \mathrm{IBA}$ performed the best. All the transplanted plantlets survived in the natural environment. The present protocol is simple, with very less input of phytohormone and is genotype independent.

The present protocol was found to be most suitable for stress tolerant potato varieties. Using this protocol it will be possible to produce plantlets of potato in large scale so that we can cultivate those in the saline affected coastal region. This is, furthermore, helpful for achieving local food security because rice is not growing well in the saline zones. Thus, the present protocol can be used for commercial production of potato plantlets for cultivation in saline affected areas of Bangladesh to enhance food security.

\section{References}

BBS (2012) The Statistical Yearbook of Bangladesh, Statistics and Information Management Division, Ministry of Planning. pp. 238.

Borna RS, Hoque MI and Sarker RH (2010) Agrobacterium-mediated genetic transformations for local cultivars of potato (Solanum tuberosum L.) using marker genes. Plant Tissue Cult. \& Biotech. 20(2): 145-155.

Das DK, Dey BR, Mian MJA and Hoque MA (2013) Mitigation of the adverse effects of salt stress on maize (Zea mays L.) through organic amendments. Int. J. Appl. Sci. Biotechnol. 1(4): 233-239.

Haberlacha GT, Cohenc BA, Reichertb NA, Baerc MA, Towilla LE and Helgeson JP (1985) Isolation, culture and regeneration of protoplasts from potato and several related Solanum species. Plant Science 39:67-74.

Hoque MI, Islam MA, Sarker RH and Islam AS (1996) In vitro microtuber formation in potato (Solanum tuberosum L.). In: Plant Tissue Culture (Ed. A.S. Islam), Oxford \& IBH Publ. Co., Calcutta/New Delhi, pp. 221-228.

Hussain I, Muhammad A, Chaudhury Z, Asghar R, Naqvi SMS and Rashid H (2005) Morphogenic potential of three potato (Solanum tuberosum L.) cultivars from diverse explants, a prerequisite in genetic manipulation. Pakistan J. Bot. 37(4):889-898.

Khatun A, Hasan MM, Bachchu MAA, Moniruzzaman M and Nasiruddin KM (2012) Agrobacterium-mediated genetic transformation of potato (Solanum tuberosum L.) var. Cardinal and Heera. The Agriculturists 10 (1): 81-86.

Khatun MM, Molla MMH and Akhond MAY (2011) In vitro screening of potato cultivars for relative salt tolerance. Research Report 2010-2011. Biotechnology Division, Bangladesh Agricultural Research Institute, Gagipur. p-24.

Khatun MM, Akhond MAY, and Molla MMH (2010) In vitro screening of potato cultivars for relative salt tolerance. Research Report 2009-2010. Biotechnology Division, Bangladesh Agricultural Research Institute, Gazipur. http://180.211.164.225/rmis/ index.php?t=detail_info\&linkid=10024

Philip JD and Hampson KK (1995) An assessment of morphogenic and transformation efficiency in a range of varieties of potato (Solanum tuberosum L.). Euphytica 85:101108. 
Rahman MH, Patwary MMA, Barua H, Hossain M and Hasan MM (2013) Screening of salt tolerant CIP potato germplasm for saline areas. The Agriculturists 11(1): 95-102.

Ritchie SW and Hodges TK (1993) Cell culture and regeneration of transgenic plants. In: Transgenic plants. (Eds.): S. Kung and R. Wu., Academic Press, London. 1: 147-178.

Sarker RH and Mustafa BM (2002) Regeneration and Agrobacterium-mediated genetic transformation of two indigenous potato varieties of Bangladesh. Plant Tiss. Cult. 12(1): 69-77.

Sharfuddin AFM and Siddique MA (1985) Shobji Biggan (In Bengali). Published by Mrs. Hasina Akther Beauty, E-26/2 Residential area, BAU Campus, Mymensingh. pp.184.

Shirley Y, Brit S, Shirlyn C, Jane EAS and Xiu-Qing L (2001) High efficiency regeneration in vitro from potato petioles with intact leaflets. Amer. J. Potato Res. 78: 151-157.

Trujillo C, Arengo ER, Jaramillo S, Hoyos R, Orduz S and Arango R (2001) One step transformation of two Andean potato cultivars (Solanum tuberosum L. subsp. Andigena). Plant Cell Rep. 20: 639-641.

Uddin MA, Yasmin S, Rahman ML, Hossain SMB and Choudhury RU (2010) Challenges of potato cultivation in Bangladesh and developing digital databases of potato. Bangladesh J. Agril. Res. 35(3): 453-463.

Uddin MS, Khan MSI, Talukdar MMR, Hossain MI and Ullah MH (2011) Climate change and salinity in Bangladesh: constraints and management strategy for crop production. Rajshahi Univ. Jour. Environ. Sci. 1(1): 13-20. 